\title{
ALFA 1 ANTITRIPSINO FENOTIPŲ REIKŠMĖ LĖTINĖS OBSTRUKCINĖS PLAUČIŲ LIGOS GENEZĖJE
}

\author{
DANIELIUS SERAPINAS, DOC. DR. BRIGITA ŠITKAUSKIENĖ, PROF. DR. RAIMUNDAS SAKALAUSKAS \\ KMU PULMONOLOGIJOS IR IMUNOLOGIJOS KLINIKA
}

\begin{abstract}
Reikšminiai žodžiai: alfa1 antitripsino stoka, fenotipai, lètinẻ obstrukcinẻ plaučių liga.
Santrauka. Polinkis sirgti lètine obstrukcine plaučių liga (LOPL) nulemtas tiek išorinės aplinkos, tiek genetinių veiksnių. Nors rūkymas yra vienas pagrindinių lètinès obstrukcinès plaučių ligos rizikos veiksnių, egzistuoja ir įrodytas genetinis polinkis sirgti šia liga, kai yra igimta alfa 1 antitripsino (AAT) stoka. Alfa 1 antitripsino stoka - viena dažniausių europiečių genetinių ydų, pažeidžianti maždaug 1 iš 1600-3000 asmenų. AAT - proteazių inhibitorius, apsaugantis plaučių audini nuo žalingų išorinės ir vidinių veiksnių. Kai stinga šios antiproteazės, ardomos alveolių sienelès ir formuojasi lètinè obstrukcinė plaučiu liga arba emfizema. AAT stoka statistiškai reikšmingai susijusi su ankstyvu LOPL pasireiškimu ir sparčiu ligos progresavimu, invalidumu, trumpesne gyvenimo trukme. AAT stoka diagnozuojama 1-3 proc. LOPL sergančių asmenų. Tipinės AAT stokos atvejais žmogus turi būti gavęs po pakitusį PI geną (PI Z, PI S, PI Null) iš abiejų tèvu, nes liga paveldima autosominiu recesyviniu būdu. Daugeliui LOPL sergančių pacientu AAT stoka lieka nediagnozuota. Taigi ankstyva LOPL pacientų patikra dèl alfa 1 antitripsino stokos - svarbi ligos priežastiniam veiksniui nustatyti, ligos eigai prognozuoti, gydymui bei profilaktikai.
\end{abstract}

\section{IVADAS}

Alfa 1 antitripsino stoka pirmą kartą aprašyta 1963 metais, bet ligos genetika, patofiziologija ir galimybès gydyti geriau suprastos tik pastaraisiais metais.

AAT - vienas pagrindinių proteazių inhibitorių, priklausantis serpinų šeimai (serino proteazių inhibitoriams). AAT koduoja 12,2 kb PI (proteazès inhibitoriaus) genas, sudarytas iš 7 egzonų ir 6 intronų, esantis 14q31-31.2 chromosomoje [1]. Dažniausias alelis, lemiantis AAT stygių, yra PI Z, kuris būdamas homozigotinès formos (PI ZZ) mažina AAT koncentraciją serume. Šio baltymo stoką serume ir audiniuose, ìskaitant ir plaučius, lemia dviejų proteazių inhibitoriụ - mutavusių AAT alelių - paveldejimas.

Didžioji AAT dalis sintetinama kepenų ląstelèse, tačiau ši glikoproteiną išskiria ir monocitai, makrofagai bei plaučių alveolių epitelio ląstelès. Tai ūminès fazès baltymas, jo koncentracija plazmoje didejja esant uždegimui ar infekcijai. Medžiaga taip pavadinta dèl gebejjimo slopinti tripsiną, tačiau pagrindinẻ jos funkcija - slopinti neutrofilų elastazę (NE), ardančią audinių elastiną, esantị už ląstelių ribų. Z molekulès variantas, kuris yra dažniausias fenotipas, lemiantis LOPL, sąlygoja normalų mRNR ir antitripsino sintezès greiti, tačiau šiuo atveju AAT molekulès struktūra ir funkcija būna pakitusios dèl polimerizacijos ir tik 15 proc. medžiagos patenka ị bendrą kraujotaką. 85 proc. pagaminto antitripsino lieka sukaupta hepatocituose, šios sankaupos gali būti per mikroskopą matomos kaip dideli intarpai citoplazmoje. Lètinè obstrukcinè plaučių liga yra dažniausia šios medžiagos stokos klinikinė išraiška, taip pat ir pagrindine šių ligonių invalidumo ir mirties priežastis.

LOPL yra patologinė būklè, kuriai būdinga nevisiškai išnykstanti, progresuojanti ir neịprastą plaučių uždegimo atsaką i itkvepiamas kenksmingas daleles lemianti bronchų obstrukcija. Liga pasireiškia plaučių emfizemos ir lètinio bronchito požymiais. LOPL patogenezei svarbus ne tik genetinių ar aplinkos veiksnių poveikis, bet ir šių veiksnių tarpusavio sąveika [2]. Visame pasaulyje vyksta tyrimai, skirti analizuoti šiuos veiksnius.

Jei rūkantis asmuo stokoja AAT, emfizema atsiranda 10-15 metų anksčiau nei rūkaliams, kuriems AAT nestinga. AAT stoka statistiškai reikšmingai susijusi su ankstyvu LOPL pasireiškimu ir sparčiu ligos progresavimu, invalidumu, trumpesne gyvenimo trukme. AAT stokojantiems pacientams emfizema dažniausiai pasireiškia jau apie keturiasdešimtuosius gyvenimo metus [3]. AAT trūkumas nustatomas 1-3 proc. LOPL sergančių ligonių [4].

Izoelektrinio fokusavimo technologija nustatyta apie 100 genetinių AAT variantų. Abécèlinis šių variantuc suskirstymas remiasi juc judrumo greičiu elektoforezès plokštelèje. Greičiau judantys variantai žymimi 
pirmesne abècèlès raide, o lèčiau judantys - tolesne ( $Z$ variantas juda lèčiausiai). M1, M2, M3 ir M4 yra nemutacinio (angl. wild type) tipo AAT geno variantai. PI MM fenotipas yra vidutinio judrumo. Jo dažnumas europiečiu populiacijoje - 94-96 proc. [5]. Apie 2-3 proc. europiečių yra heterozigotai (PI MZ). Daugelio tyrimų suvestinès analizès rodo, kad pasaulyje 3,4 milijonai gyventojų turi genetinị PI ZZ variantą, lemianti AAT stoką. Deja, dažnam LOPL pacientui AAT stoka lieka nediagnozuota [6].

\section{EPIDEMIOLOGIJA}

Nedidelis PI ZZ fenotipo dažnumas bendrojoje populiacijoje pasunkina tikslių duomenų surinkimą. Patikslinti naujagimių sergamumą šia liga padejo kai kuriose šalyse vykdoma visuotinè naujagimių patikra AAT stokai nustatyti. Švedijoje 1972-1974 metais iš 200 tūkst. tirtų naujagimių 127 turejjo PI ZZ fenotipą. Apskaičiuotas ligos dažnumas - 1 iš 1600 naujagimių. Amerikos tyrimų duomenimis, ligos dažnumas yra 1 iš 2800-5000 naujagimių [5], o Europoje nustatytas didelis $\mathrm{Z}$ geno paplitimo svyravimas įvairiose šalyse. AAT stokos atvejų dažnumas Baltijos jūros regiono šalyse yra apie penkis kartus didesnis nei likusioje Europos teritorijoje.

AAT stoka (PI ZZ) yra paveldima autosominiu recesyviniu būdu. Tikimybè susilaukti vaiko, turinčio homozigotini genotipą, - 1 iš 4 , jei abu tèvai yra $Z$ alelio nešiotojai. Jei vienas iš tèvų turi PI ZZ genotipą, o kitas yra heterozigotas (nešiotojas), vaikai bus arba nešiotojai, arba ligoniai (PI ZZ).

\section{NEUTROFILŲ SUKELIAMO UŽDEGIMO MECHANIZMAS STOKOJANT AAT}

Neutrofiluc sukeltas kvépavimo takų uždegimas vaidina svarbų vaidmeni LOPL patogenezèje. Pakankama AAT koncentracija plaučių audinyje slopina su neutrofilų aktyvumu susijusius uždegimo mechanizmus. AAT stokojančių pacientų alveoliniai makrofagai, stimuliuojami neutrofiluc elastazès (NE), išskiria leukotrieną B4 - stiprų neutrofilų traukos veiksnị. Normaliomis sąlygomis to nebūna, nes neutrofiluc elastazè yra „surišama" AAT molekulių ir tampa neaktyvi. Be to, interleukinas-1, navikų nekrozès faktorius ir neutrofilų elastazè skatina trombocituc aktyvacijos faktoriaus (TAF) sintezę ir išsiskyrimą iš daugelio rūšių ląstelių, ìskaitant ir makrofagus. O TAF yra stiprus neutrofilų traukos (chemotaksio) veiksnys. TAF ir kituc citokinų išsiskyrimas yra slopinamas nepakitusio AAT molekulių. Kai AAT elastazę slopinantis poveikis nepakankamas, skatinamas kvèpavimo takų uždegimas ir jautrumo padidejjimas, lemiantis spartesni plaučių audinio ardymą ir persitvarkymą. Pagal naujus molekulinių tyrimų duomenis neaktyvios formos AAT molekulès polimerizuojasi, o polimerai, būdami alveolių spindyje, patys atlieka neutrofilų chemotaksio funkciją [7].

\section{AAT SOKOS KLINIKOS YPATUMAI}

Susirgimą LOPL bei ligos sunkumą esant PI ZZ fenotipui lemia daug veiksnių. Irodyta, kad rūkymas šiuo atveju yra svarbiausias veiksnys, sąlygojantis emfizemos atsiradimą. AAT stokojantiems rūkaliams spirometrijos rodmuo - forsuoto iškvèpimo tūris per 1 sekundę (FEV1) - kasmet sumažèja $130 \mathrm{ml}$, o metusiųjų rūkyti - $70 \mathrm{ml}$ [8]. Vèlesnių tyrimų duomenimis, per metus rūkančiųjų FEV1 sumažèja - $70 \mathrm{ml}$, niekada nerūkiusiųjų - $47 \mathrm{ml}$, o metusiųjų rūkyti - $41 \mathrm{ml}$. Rezultatai rodo, kad metus rūkyti ir niekada nerūkius FEV1 mažèjimo greitis esti panašus. Iš kitų veiksnių, turinčių ịtakos spartesniam kvẻpavimo funkcijos rodiklių blogejimui, galima paminèti dažną kvėpavimo takų bakterinių ir virusinių infekcijų paūmėjimą, darbą su kenksmingomis cheminėmis medžiagomis ar aerozolio dulkèmis, vyresnị amžių bei vyriškąją lytị. Skirtingą lètinès obstrukcinès ligos sunkumą AAT stokos atvejais galima paaiškinti tuo, kad LOPL pasireiškimui turi reikšmès ir kiti genetiniai veiksniai: matrikso metaloproteazių, alfa 1 chimotripsino, navikų nekrozès faktoriaus, D vitaminą sujungiančio baltymo, HLA genai. LOPL priklauso daugiakilmių ligu grupei. Todèl net ir PI ZZ genotipas ne visada yra nuosprendis neišvengiamai susirgti LOPL: kai kuriems nerūkantiems asmenims emfizemos gali ir nebūti, o jụ gyvenimo trukmè nesutrumpeja [9]. Tai, matyt, priklauso nuo genetinių determinantų, lemiančių kitus apsauginius plaučių mechanizmus. Daliai pacientų, stokojančiuc AAT (dažniausiai PI ZZ fenotipo), išryškejja hepatito požymių, o po 50-ųjų gyvenimo metų net keliolika kartų padidejja tikimybė susirgti kepenų vẻžiu. Išimtis - pacientai, turintys AAT stokos fenotipą PI NullNull, kuris nedidina rizikos sirgti kepenų ligomis. Kai kurių tyrèjų atlikti tyrimai rodo AAT susijus ir su kitomis ligomis. Vaikų, sergančiuc glomerulonefritu su nefroziniu sindromu, kraujo serume buvo nustatyta mažesnè AAT koncentracija [10].

\section{AAT STOKOS DIAGNOSTIKA}

Paprasčiausias būdas nustatyti AAT stoką - ištirti AAT koncentraciją serume. Normali AAT yra nuo 1 iki 2,6 g/l. Dažniausio stokos varianto (PI ZZ) atveju koncentracija tesiekia 20 proc. normalios (paprastai mažiau kaip 0,3 g/l), o nešiojimo (PI MZ) atveju - 80 proc. Diagnozuojant taikomi šiuolaikiniai tyrimai, kaip antai kokybinis imunofermentinis tyrimas, kuriuo nustatomas mutavęs AAT „Z“ alelis, daugiau skirtini patikrai [11]. Tikslus AAT fenotipas nustatomas izoelektriniu fokusavimu. Dažniausias fenotipas - PI MM, jis yra normos variantas ir pasitaiko apie 94 proc. atvejų. Kiti fenotipai: PI ZZ, PI ZNull, PI NullNull, PI SZ (lemiantys dideli AAT stygiu), PI SS, PI SNull, PI MNull, PI MZ, PI MS (lemiantys lengvesnio laipsnio AAT stygiu). Molekuliniais genetiniais tyrimais nustatoma mutacija, lemusi patologinị fenotipą. 
Kiekybinio AAT tyrimo atlikimo rekomendacijos (tikimybès aptikti patologiją mažejimo tvarka):

1. Ankstyva plaučiuc emfizema (iki 45 metú amžiaus).

2. Visi asmenys, sergantys LOPL.

3. AAT stoką turinčiuc pacientų šeimos nariai.

4. Dusulys ir letinis kosulys, varginantis daugelį giminaičių, tos pačios ar kitų kartų.

5. Nežinomos kilmès kepenų liga.

6. Suaugę asmenys, sergantys nežinomos kilmès bronchektazèmis.

7. Astma sergantys asmenys, kurių spirometrijos rodikliai gydant nesinormalizuoja.

8. Itariamas antiproteazès-3 vaskulitas.

\section{PROGNOZĖ IR LIGOS AKTUALUMAS}

Keletu tyrimu nustatyta, kad FEV1 rodmuo yra tiksliausias AAT stokojančių LOPL pacientų išgyvenamumo prognozès rodiklis. Danijos AAT stokos registro duomenimis, kol FEV1 viršijo 35 proc. išgyvenančiųjų dvejus metus nemažèjo. Asmenų, turinčių PI ZZ genotipą, kurių FEV1 nesiekè 35 proc., 2 metų išgyvenamumas mažejjo eksponentiškai, priklausomai nuo FEV1 mažejjimo greičio. Kai FEV1 rodiklis buvo 15 proc., per dvejus metus mirè 50 proc. ligoniu [9].

Nustatyti genetinius pokyčius ligoniams svarbu ir dèl to, kad tada galima taikyti pakeičiamąji gydymą alfa 1 antitripsinu, kuris padeda pristabdyti ligos progresavimą, užkirsti kelią priešlaikiniam invalidumui ir net mirčiai [12]. Išsiaiškinus šios genetinès ligos atvejus, sudaromas specialus pacientų sveikatos būklès stebejimo planas. Rekomenduojamos profilaktikos priemonès yra skiepai nuo gripo ir pneumokokinė vakcina. Ligoniams kategoriškai draudžiama rūkyti.

Deja, dauguma alfa 1 antitripsino stokos atvejų lieka nediagnozuoti, taigi būtina vykdyti atrankinių pacientų grupių, ypač sergančių LOPL, patikrą dèl AAT stokos.

\section{IŠVADOS}

1. Alfa 1 antitripsino stoka - patikimai ịrodytas genetinis veiksnys, lemiantis didesnę riziką susirgti lètine obstrukcine plaučiuc liga. Šiuo atveju lètinès obs-

\section{LITERATŪRA}

1. Cox DW, Woo SLC, Mansfield T. DNA restriction fragments associated with a-1-antitrypsin indicate a single origin for deficiency allele PI Z. Nature 1985;316:79-81.

2. Dawn L. DeMeo, Edwin K. Silverman. Genetics of Chronic Obstructive Pulmonary Disease. 2003 Semin Respir Crit Care Med 24(2):151-159.

3. Silva GE, Sherrill DL, Guerra S, et al. A longitudinal study of alpha-1-antitrypsin phenotypes and decline in FEV1 in a community population. Chest 2003;123:1435-40.

4. Richmond RJ, Zellner KM Alpha1-antitrypsin deficiency: incidence and implications. Dimens Crit Care Nurs. 2005 Nov-Dec;24(6):255-60.

5. De Serres F. Worldwide racial and ethnic distribution of alpha-1-antitrypsin deficiency: summary of an analysis of published genetic epidemiologic surveys. Chest 2002;122:1-12.

6. Zielinski J, Kuca P. Alpha-1 antitrypsin deficiency: a cause of COPD not sufficiently recognized in Poland. Pneumonol Alergol Pol. 2004;72(910):364-6.

7. Lomas DA. Antitrypsin deficiency, the serpinopathies, and chronic ob- trukcinès plaučiu ligos eiga būna sunkesnè, liga greičiau progresuoja ir trumpina paciento gyvenimo trukmę.

2. Didžioji dalis tyrimų rodo, kad, palyginti su bendrąja populiacija, PI Z geno nešiotojams (PIMZ ir PISZ) gresia didesnè rizika susirgti lètine obstrukcine plaučių liga.

3. Daugumai lètine obstrukcine plaučių liga sergančių pacientuc alfa 1 antitripsino stoka lieka nediagnozuota, taigi būtinas didesnis gydytojų budrumas šios ligos diagnostikos klausimais.

4. Anksti diagnozavus ligą, immanomas veiksmingas pakeičiamasis gydymas alfa 1 antitripsinu. Išsiaiškinus sveikus asmenis, kuriems gresia didesnè rizika susirgti lètine obstrukcine plaučių liga, galima laiku imtis profilaktikos priemonių. Taip pat svarbu pacientams paaiškinti genetinę prognozę: labai gali būti, kad liga sirgs ir kiti šeimos nariai.

\section{ALPHA-1 ANTITRYPSIN PHENOTYPES DURING CHRONIC OBSTRUCTIVE PULMONARY DISEASE}

\section{DANIELIUS SERAPINAS, BRIGITA ŠITKAUSKIENĖ, RAIMUNDAS SAKALAUSKAS DEPARTMENT OF PULMONOLOGY AND IMMUNOLOGY KAUNAS UNIVERSITY OF MEDICINE}

Key words: alpha-1 antitripsin deficiency, phenotypes, chronis obstructive pumonary disease.

Summary. Variability in the susceptibility to develop chronic obstructive pulmonary disease (COPD) is related to both genetic and environmental factors. Smoking is one of the main evidenced risk factor for COPD, but alpha- 1 antitrypsin (AAT) deficiency remains proven genetic risk factor for COPD. Alpha- 1 antitrypsin deficiency is one of the most common genetically-linked lethal diseases among Caucasians, affecting approximately 1 in every 1600-3000. Alpha- 1 antitrypsin is a serine protease inhibitor (serpin). It protects lung tissue from destructive exogenous and endogenous factors. A lack of alpha- 1 antitrypsin leads to alveolar destruction and development of COPD or pulmonary emphysema. Affected individuals become invalid in a shorter time. For 1-3\% individuals with COPD, alpha-1 antitrypsin deficiency is determined. AAT deficiency is disorder which is transmitted in a co-dominant, autosomal form. Mutant alleles (Z, S, Null) individual inherits from both parent and this can lead to severe Alpha-1 antitrypsin deficiency. AAT deficiency is an underdiagnosed condition in patients with COPD. We accentuate the importance of early analysis of alpha-1 antitrypsin in patients with COPD to determine exact disease reason - alpha-1 antitrypsin deficiency, it's prognosis, treatment and prevention.

structive pulmonary disease. Proc Am Thorac Soc. 2006 Aug;3(6):49950

8. Mcelvaney NG et al. Alpha-1 Antitrypsin Deficiency Group. Baseline characteristics of enrollees in the National Heart, Lung, and Blood Institute Registry of a-1 Antitrypsin Deficiency. Chest 1997;111:394-403.

9. Seersholm N, Kok-jensen A, Dirksen A. Survival of patients with severe with a-1-antitrypsin deficiency with special reference to non index cases. Thorax 1994;49:695-698.

10. Kaltianis PA, Basis Vlu, Ignatova MS, Stakishaitis DV, Baukene DK, Dlin VV, Bondarenko NA. Study of serum levels of alpha 1-antitrypsin and alpha macroglobulins in children with glomerulonephritis. Pediatriia. $1991 ;(7): 66-9$

11. Costa X., Jardi R, Rodriguez F, Miravitlles M, Cotrina M, Gonzalez C, et al. Simple method for a1- antitrypsin deficiency screening by use of dried blood spot specimens. Eur Respir J 2000;15:1111-5.

12. Abusriwil H, Stockley RA. Alpha-1-antitrypsin replacement therapy: current status. Curr Opin Pulm Med. 2006 Mar;12(2): 125-31. 